\title{
Evident elevation of atmospheric monoterpenes due to degradation-induced species changes in a semi-arid grassland
}

\author{
Hongjun Wang ${ }^{\mathrm{a}, \mathrm{b}, *, 1}$, Xinming Wang ${ }^{\mathrm{b}}$, Yanli Zhang ${ }^{\mathrm{b}}$, Yujing $\mathrm{Mu}^{\mathrm{c}}$, Xingguo Han ${ }^{\mathrm{a}, \mathrm{d}}$ \\ a State Key Laboratory of Vegetation and Environmental Change, Institute of Botany, Chinese Academy of Sciences, Xiangshan, Beijing 100093, China \\ b State Key Laboratory of Organic Geochemistry, Guangzhou Institute of Geochemistry. Chinese Academy of Sciences, Guangzhou 510640, China \\ ' Research Center for Eco-Environmental Sciences, Chinese Academy of Sciences, Beijing 100085, China \\ d State Key Laboratory of Forest and Soil Ecology, Institute of Applied Ecology, Chinese Academy of Sciences, Shenyang 110164, China
}

\section{H I G H L I G H T S}

- Ambient BVOCs concentrations were measured in a degraded semi-arid grassland.

- Degraded grassland may become a significant BVOCs source to the atmosphere.

- Climate change-induced vegetation change alters ambient BVOCs concentration.

- A. frigida and sedge emit high monoterpenes and isoprene, respectively, in grassland.
GRA PH ICA L A B STRACT

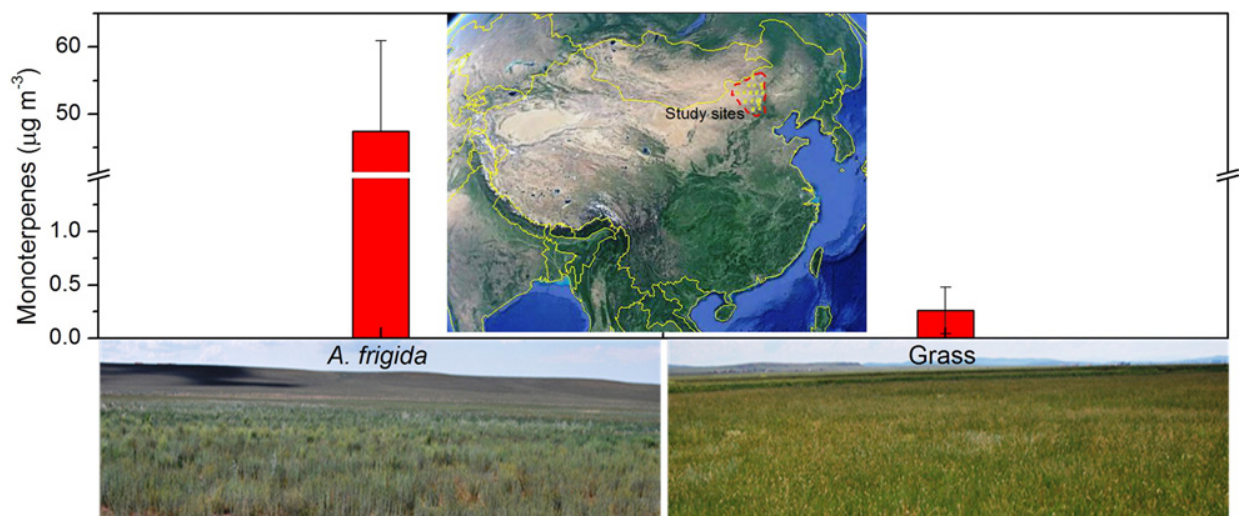

\section{A B S T R A C T}

Biogenic volatile organic compounds (BVOCs) emitted from plants have substantial effects on atmospheric chemistry/physics and feedbacks on ecosystem function. The on-going climate change and anthropogenic disturbance have been confirmed to cause the evident degradation of grassland with shift of plant community, and hence BVOCs emissions were suspected to be altered due to the different BOVCs emission potentials of different species. In this study, we investigated BVOCs concentration above ground surface during growing season in a degraded semi-arid grassland $\left(41^{\circ} 2^{\prime} \mathrm{N}-45^{\circ} 6^{\prime} \mathrm{N}, 113^{\circ} 5^{\prime}-117^{\circ} 8^{\prime}\right)$ in Inner Mongolia. The observed monoterpenes' concentrations varied from 0.10 to $215.78 \mu \mathrm{g} \mathrm{m}^{-3}$ (34.88 $\pm 9.73 \mu \mathrm{g} \mathrm{m}^{-3}$ in average) across 41 sites. Compared to nondegraded grassland, concentrations of monoterpenes were about 180 times higher at the sites dominated by subshrub - Artemisia frigida, a preponderant species under drought stress and over-grazing. The biomass of $A$. frigida explained $51.39 \%$ of the variation of monoterpenes' concentrations. $\alpha$-pinene, $\beta$-pinene and $\gamma$-terpinene dominated in the 10 determined monoterpenes, accounting for $37.72 \pm$ $2.98 \%, 14.65 \pm 2.55 \%$ and $10.50 \pm 2.37 \%$ of the total monoterpenes concentration, respectively. Low isoprene concentrations $\left(\leq 3.25 \mu \mathrm{g} \mathrm{m}^{-3}\right.$ ) were found and sedge biomass contributed about $51.76 \%$ to their spatial variation. $\alpha$-pinene and isoprene emissions at noon were as high as $515.53 \pm 88.34 \mu \mathrm{g} \mathrm{m}^{-2} \mathrm{~h}^{-1}$ and

\footnotetext{
* Corresponding author at: State Key Laboratory of Vegetation and Environmental Change, Institute of Botany, Chinese Academy of Sciences, 20 Nanxincun, Xiangshan, Beijing 100093, China.

E-mail address: hjwang78@gmail.com (H. Wang).

${ }^{1}$ Present address: Nicholas School of the Environment, Duke University, Durham, NC 27708, USA.
} 
$7606.19 \pm 1073.94 \mu \mathrm{g} \mathrm{m}^{-2} \mathrm{~h}^{-1}$ in $A$. frigida- and sedge-dominated areas where their biomass were $236.90 \mathrm{~g} \mathrm{~m}^{-2}$ and $72.37 \mathrm{~g} \mathrm{~m}^{-2}$, respectively. Our results suggested that the expansion of A. frigida and sedge caused by overgrazing and climatic stresses may increase local ambient BVOCs concentration in grassland.

(c) 2015 Elsevier B.V. All rights reserved.

\section{Introduction}

Some plants emit substantial biogenic volatile organic compounds (BVOCs), which may significantly impact air quality and biosphere structure/function (Fuentes et al., 2001; Guenther et al., 1995; Lerdau, 2007; Peñuelas, 2008; Peñuelas and Llusià, 2003; Peñuelas and Staudt, 2010; Shallcross and Monks, 2000). It is well known that BVOCs are important for plants in defense against abiotic and biotic stresses (Frost et al., 2008; Peñuelas and Llusià, 2003). Extensive studies suggest that plants with strong BVOCs emission may expand, because they gain more protection by releasing BVOCs in the face of abiotic stressors, like warming, drought, elevated $\mathrm{CO}_{2}$ and $\mathrm{UV}$, compared to low and non-BVOCs emitting plants (Lerdau, 2007; Loreto and Schnitzler, 2010; Peñuelas, 2008; Peñuelas and Llusià, 2003; Peñuelas and Staudt, 2010). Thus, the ambient BVOCs concentration may increase, but still lack of evidence, in some climate-sensitive ecosystems where the high BVOCs emission plants may expand due to climate change. Valolahti et al. (2015) recently investigated how long-term warming (13 years of treatment) affects the BVOCs emission in subarctic ecosystems. Other than the direct effect of warming, their results show that climate warming-induced vegetation change is the major factor indirectly increasing the BVOCs emission (Valolahti et al., 2015).

Grassland, as one of the major biome types, covers about one-quarter of earth's land surface. Generally, the dominant herbaceous species in non-degraded grassland emit low BVOCs (Guenther et al., 2006). However, grassland is undergoing significant changes due to climate change and anthropogenic disturbance (Guenther et al., 1995; Lerdau and Slobodkin, 2002). Currently degradation is the most severe ecological problem in the Eurasian grassland - one of the largest contiguous terrestrial biomes (Werger and van Staalduinen, 2012). Shrub encroachment has been observed in many native grasslands globally over the past two centuries (Idso, 1992; Liu, 2003; Morgan et al., 2007). The newly dominant species, which adapt to stressed conditions, may substantially impact the community-level BVOCs emission and hence the ambient BOVCs concentration. A study in a semi-arid grassland of Inner Mongolia discovered that subshrub - A. frigida, as an overgrazing indicator, is an important monoterpene emitter, whose emission factor based on dry biomass was about 20 times higher than grass (Wang et al., 2012). A. frigida is a common subshrub in North American and Eurasian grasslands and its abundance tends to increase globally under elevated $\mathrm{CO}_{2}$ concentration and anthropogenic disturbance (Liu, 2003; Morgan et al., 2007; Werger and van Staalduinen, 2012). In the Colorado shortgrass steppe in USA, 5-year double $\mathrm{CO}_{2}$ enrichment resulted in a 20 -fold increase in A. frigida coverage (Morgan et al., 2007). Currently more than $60 \%$ of grassland in China has been degraded by over-grazing and climate change. Remote sensing data and field investigation (Liu, 2003) have shown that between 1960 and 2000 , A. frigida coverage increased by 10 times in the Xilinguole region ( $20 \%$ of total area in Inner Mongolia). Therefore, ambient BVOCs concentration in grassland may increase globally.

In this study, we investigated ambient BVOCs concentrations during the growing season in a temperate semi-arid grassland in Inner Mongolia that represents the Eurasian grassland ecosystem. Our aim was to give (1) a first overview on the ambient BVOCs concentrations (isoprene and monoterpene) near ground surface in degraded and non-degraded grasslands, and (2) to assess the effect of species changes and environmental conditions on ambient BVOCs concentration in arid and semi-arid grassland.

\section{Materials and methods}

\subsection{Site description}

The sampling sites were located in a typical semiarid grassland in Xilinguole League of Inner Mongolia $\left(41^{\circ} 35^{\prime}-46^{\circ} 46^{\prime} \mathrm{N}, 111^{\circ} 09^{\prime}-\right.$ $\left.119^{\circ} 58^{\prime}\right)$. Xilinguole League covers about $2 \times 10^{5} \mathrm{~km}^{2}$ including two county-level cities, one county and nine banners. Historically, Stipa grandis and Leymus chinensis have been the dominant species in this region. However, over-grazing and drought have significantly increased the abundance of $A$. frigida, and $A$. frigida is becoming the dominant species (Liu, 2003). In this study, we focused on the degraded grassland dominated by $A$ frigida. In total, 31 degraded sites (2-4 sites in each county and banner excluding cities) were included, 24 sites dominated by A. frigida, 3 sites by Artemisia sieversiana and 4 sites by Artemisia ordosica. In order to compare with non-degraded grassland, another 10 sites covered by S. grandis, L. chinensis and/or sedge (mainly Carex korshinskyi Kom) were selected. All sites were far away from road and city, and the covering area of dominant species except sedge at each site was larger than 1 ha.

\subsection{Ambient BVOCs sampling and analysis}

Stainless-steel electro-polished canisters (2 L) provided by University of California, Irvine (UCI) were used to sample ambient air at a height of $0.2 \mathrm{~m}$ above plant canopy. All canisters were cleaned to $-50 \mathrm{mTorr}$ by a vacuum cleaner (Entech $3100 \mathrm{~A}$ ) in lab. Gas samples were collected between 9:00 am and 3:00 pm from 22 July to 8 August 2009. All gas samples were transported to State Key Laboratory of Organic Geochemistry at Guangzhou Institute of Geochemistry, Chinese Academy of Sciences for BVOCs analysis. At each site, we harvested all aboveground plants in a $0.5 \times 0.5 \mathrm{~m}$ quadrat to measure biomass.

Concentrations of BVOCs were determined by a Model 7100 preconcentrator (Entech Instruments Inc., California, USA) coupled with an Agilent $5973 \mathrm{~N}$ gas chromatography-mass selective detector (GC-MSD, Agilent Technologies, USA). Detailed cryogenic concentration steps are described elsewhere (Wang and Wu, 2008; Yi et al., 2007; Zhang et al., 2013). Briefly, $250 \mathrm{~mL}$ air inside the canister was first concentrated through a liquid-nitrogen cryogenic trap at $-160{ }^{\circ} \mathrm{C}$. The trapped BVOCs were then transferred by pure helium to a secondary trap at $-40{ }^{\circ} \mathrm{C}$ with Tenax-TA as adsorbent. Most of the $\mathrm{H}_{2} \mathrm{O}$ and $\mathrm{CO}_{2}$ were removed during these two steps. The secondary trap was then heated to get target BVOCs transferred by helium to a third cryo-focus trap at $-70{ }^{\circ} \mathrm{C}$. After the focusing step, the trap was rapidly heated and the BVOCs were transferred to the GC-MSD system. The mixture was first separated by an HP-1 capillary column (HP-1, $60 \mathrm{~m} \times 0.32 \mathrm{~mm} \times 1.0 \mu \mathrm{m}$, Agilent Technologies, USA) with helium as carrier gas and determined by MSD. The GC oven temperature was programmed to be initially at $-50{ }^{\circ} \mathrm{C}$, held for $3 \mathrm{~min}$; ramped at 15 ${ }^{\circ} \mathrm{C} \mathrm{min}{ }^{-1}$ up to $10{ }^{\circ} \mathrm{C}$; then raised to $250{ }^{\circ} \mathrm{C}$ at $5{ }^{\circ} \mathrm{C} \mathrm{min}{ }^{-1}$ for $10 \mathrm{~min}$. Triplicate samples were analyzed for each canister. Standard gas provided by Rowland/Blake group in UCl was used to identify and quantify isoprene and monoterpenes. The MSD was used in selected ion monitoring (SIM) mode and the ionization method was electron impacting (EI).

\subsection{Diurnal variations of BVOCs emission and ambient concentration}

Because ambient concentrations of monoterpenes significantly correlated to the biomass of $A$. frigida and isoprene to sedge, we sampled 
separately in areas dominated by A. frigida and sedge (C. korshinskyi Kom) to determined diurnal variations of monoterpene and isoprene emission in summer. Gas emission was determined by static chamber technique (Wang et al., 2012) every 1-3 h at Duolun Restoration Ecology Research Station $\left(42^{\circ} 50^{\prime} \mathrm{N}, 116^{\circ} 18^{\prime} \mathrm{E}\right.$ ) in Inner Mongolia. Our gas chamber contained an upper chamber and pedestal (Supplementary Fig. 1). The upper chamber was built from Teflon film (140 $\mu$ m thickness) enclosed around stainless-steel-framework (35 cm height, $40 \mathrm{~cm}$ diameter). The stainless-steel pedestal ( $5 \mathrm{~cm}$ height) had a gutter around the outside of the upper rim that was filled with water to create a seal with the upper chamber during sampling. Two gas samples were taken at 3-4 min intervals from the chambers by syringe, and the temperature in the chamber was recorded at the start and end of the sampling. The emission rate was calculated from the linear change of concentrations in the chamber headspace as a function of time, base area, chamber volume, and the molar volume of monoterpene or isoprene at the average air temperature in chamber.

Ambient air samples were collected by glass syringe every 20-60 min at a height of $0.2 \mathrm{~m}$ above $A$. frigida canopy. Because sedge patches were small ( $<10 \mathrm{~m}^{2}$ each) at this site, we used the concentration of the first gas sample at zero minute from our chamber as a rough ambient concentration, which might be overestimated but without wind effect. All gas samples were analyzed within two hours by gas chromatography (GC-4400, East \& West Analytical Instruments, Inc., China) with photoionization detector (PID at $10.6 \mathrm{eV}$ ). This GC-PID system can directly analyze some BVOCs without pre-concentration and allowed us to do in-situ measurements with high-frequency sampling. In this study, we reliably detected isoprene and $\alpha$-pinene. The analysis methods in detail were described by Wang et al. (2012).

\subsection{Statistical analyses}

One-way ANOVA was used to compare the difference of BVOCs concentration and biomass among sites with different dominant species. The contribution of biotic and abiotic factors to the variability of BVOCs concentration was determined by stepwise multiple linear regression. Standard errors were calculated for means and error bars in figures. $p$ values under 0.05 and $0.05-0.10$ were considered statistically significant and marginally significant, respectively. All the analyses were conducted by SAS software (SAS Institute Inc., Cary, NC, USA).

\section{Results}

\subsection{Ambient BVOCs concentration}

Across 41 sites in Xilinguole League, all gas samples and biomass were collected within two weeks in the middle of growing season. Air temperature varied between 16.1 and $36.2{ }^{\circ} \mathrm{C}$ with mean value of 27.2 ${ }^{\circ} \mathrm{C}$, and mean PAR was $1125 \mu \mathrm{mol} \mathrm{s}{ }^{-1} \mathrm{~m}^{-2}$ ranging from 212 to $1948 \mu \mathrm{mol} \mathrm{s}^{-1} \mathrm{~m}^{-2}$ when the samples were collected. Ambient concentration of total monoterpenes and isoprene showed a large variability, especially among sites with different dominant species (Fig. 1). Monoterpenes concentration ranged from 0.10 to $215.78 \mu \mathrm{g} \mathrm{m}^{-3}$ (34.88 \pm $9.73 \mu \mathrm{g} \mathrm{m}^{-3}$ in average) throughout all sites and was about 180 times higher in A. frigida-dominated areas $\left(47.41 \pm 13.52 \mu \mathrm{g} \mathrm{m}^{-3}\right)$ than in areas dominated by healthy grass species (Fig. 1a). In areas with mixed $A$. frigida and $A$. sieversiana populations and mean biomass of $1712.12 \pm 278.53 \mathrm{~g} \mathrm{~m}^{-2}$, monoterpenes concentration was as high as $88.16 \pm 39.59 \mu \mathrm{g} \mathrm{m}^{-3}$ (Fig. $1 \mathrm{a}, \mathrm{c}$ ). Regression analysis, including air temperature, PAR, biomass of different species, showed that the variability of monoterpenes concentration was mainly explained by $A$. frigida biomass (51.39\%) and PAR (4.67\%). If we only considered sites (total 8) under conditions of $A$. frigida biomass $\geq 1000 \mathrm{~g} \mathrm{~m}^{-2}$ and PAR $\geq 1000 \mu \mathrm{mol} \mathrm{s}^{-1} \mathrm{~m}^{-2}$, monoterpenes concentration reached up to $137.22 \pm 10.77 \mu \mathrm{g} \mathrm{m}^{-3}$. We mainly determined 10 monoterpene compounds including $\alpha$-pinene, $\beta$-pinene camphene, $(+)$-2-carene,
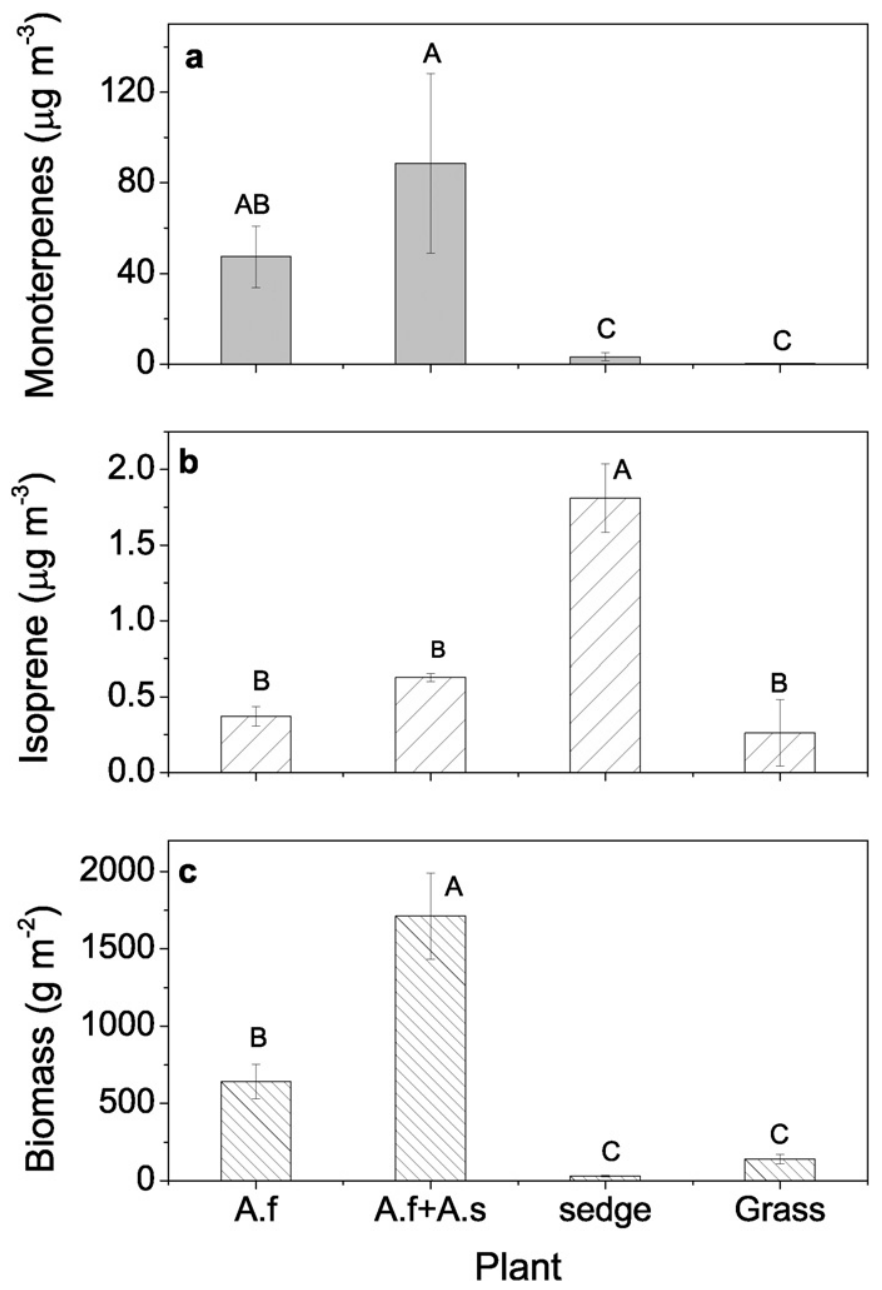

Fig. 1. Average concentrations of total monoterpenes (a) and isoprene (b), and biomass (c) in the sites dominated by $A$. frigida, A. frigida + A sieversiana, sedge and grass separately. Different letters indicated significant difference among sites.

$\beta$-myrcene, $\alpha$-phellandrene, ocimene, $\delta$-limonene, $\gamma$-terpinene and terpinolene. $\alpha$-pinene, $\beta$-pinene and $\gamma$-terpinene dominated the ambient concentration of total monoterpenes and accounted for $37.72 \pm$ $2.98 \%, 14.65 \pm 2.55 \%$ and $10.50 \pm 2.37 \%$, respectively (Fig. 2 ). When total monoterpenes concentration was lower than $2 \mu \mathrm{g} \mathrm{m} \mathrm{m}^{-3}$, terpinolene's contribution increased to $22.38 \pm 2.84 \%$ (Fig. 2). Compared to monoterpenes, isoprene concentration was lower $\left(\leq 3.25 \mu \mathrm{g} \mathrm{m}^{-3}\right)$. Mean value of isoprene concentration in sedgedominated areas (generally $<900 \mathrm{~m}^{2}$ ) was $1.81 \pm 0.23 \mu \mathrm{g} \mathrm{m}{ }^{-3}$, much higher than in other areas (Fig. 1b). Considering all sites, sedge biomass contributed about $51.76 \%$ to the variation of isoprene concentration.

\subsection{Diurnal variations of BVOCs emission and their ambient concentrations}

Ambient concentrations of both $\alpha$-pinene and isoprene showed similar diurnal variation, which spiked around noon and varied with PAR (Figs. 3a, 4). The highest ambient concentrations of $\alpha$-pinene and isoprene at noon were as high as $281.94 \mu \mathrm{g} \mathrm{m}^{-3}$ and $120.11 \mu \mathrm{g} \mathrm{m} \mathrm{m}^{-3}$ when PAR were $1806 \mu \mathrm{mol} \mathrm{s}{ }^{-1} \mathrm{~m}^{-2}$ and $1506 \mu \mathrm{mol} \mathrm{s}{ }^{-1} \mathrm{~m}^{-2}$, respectively. PAR explained $80.22 \%$ and $80.75 \%$ of the diurnal variation of $\alpha$ pinene and isoprene concentrations, respectively. $\alpha$-pinene and isoprene emission rates also had the same diurnal variation as their ambient concentration and were controlled by PAR (Figs. 3, 4). At noon $\alpha-$ pinene and isoprene emission rates reached up to $515.53 \pm$ 


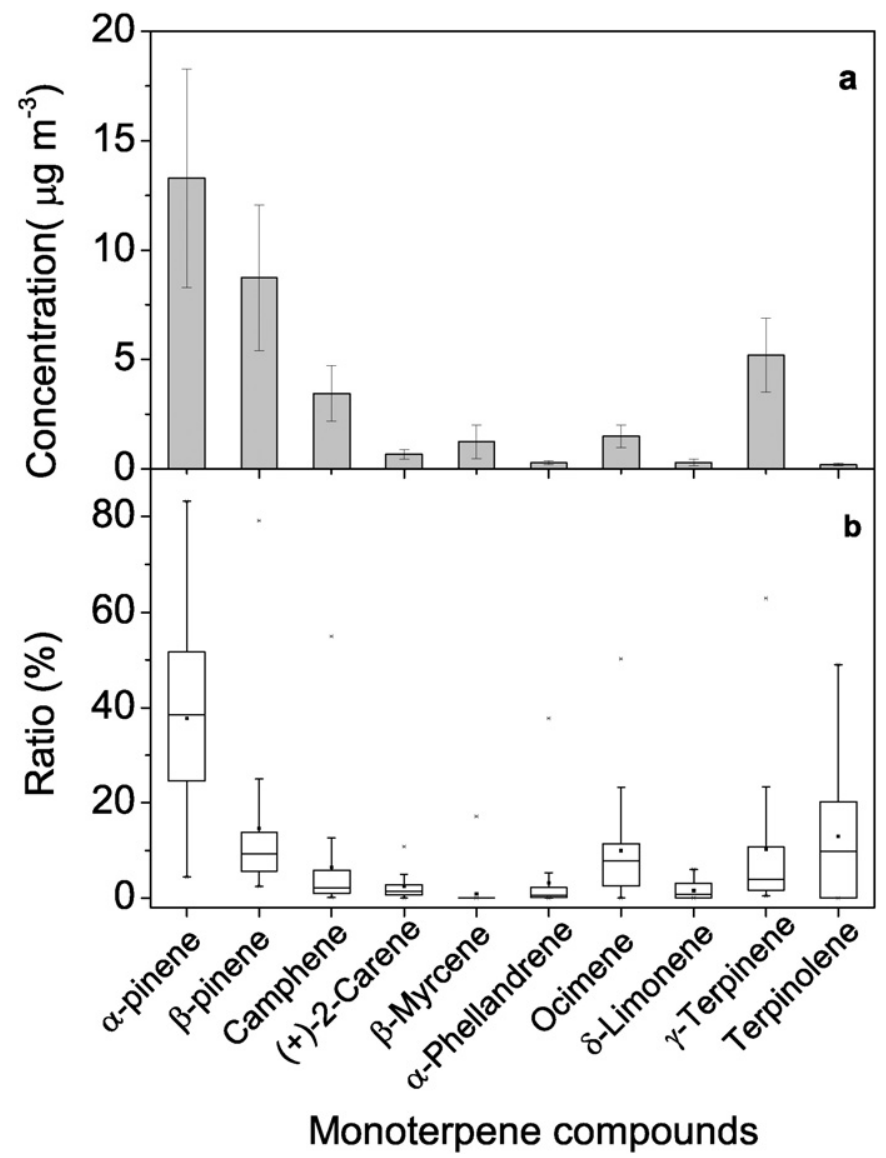

Fig. 2. Concentration of each monoterpene species (a) and the contribution of each monoterpene to the total monoterpene concentration (b) across 41 sites in Xilinguole League.

$88.34 \mu \mathrm{g} \mathrm{m}^{-2} \mathrm{~h}^{-1}$ and $7606.19 \pm 1073.9 \mu \mathrm{g} \mathrm{m}^{-2} \mathrm{~h}^{-1}$ in A. frigida and sedge dominant areas where their biomass were $236.90 \mathrm{~g} \mathrm{~m}^{-2}$ and $72.37 \mathrm{~g} \mathrm{~m}^{-2}$, respectively.
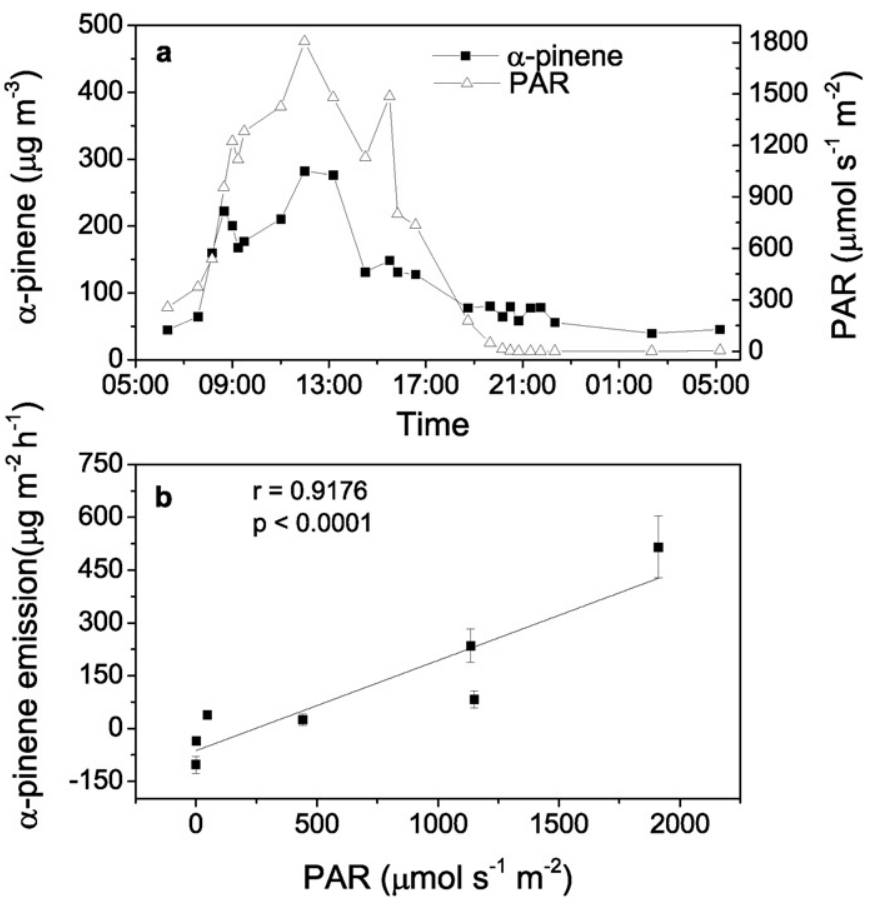

Fig. 3. Diurnal variations in ambient $\alpha$-pinene concentration (a) and the relationship between $\alpha$-pinene emission and PAR(b).

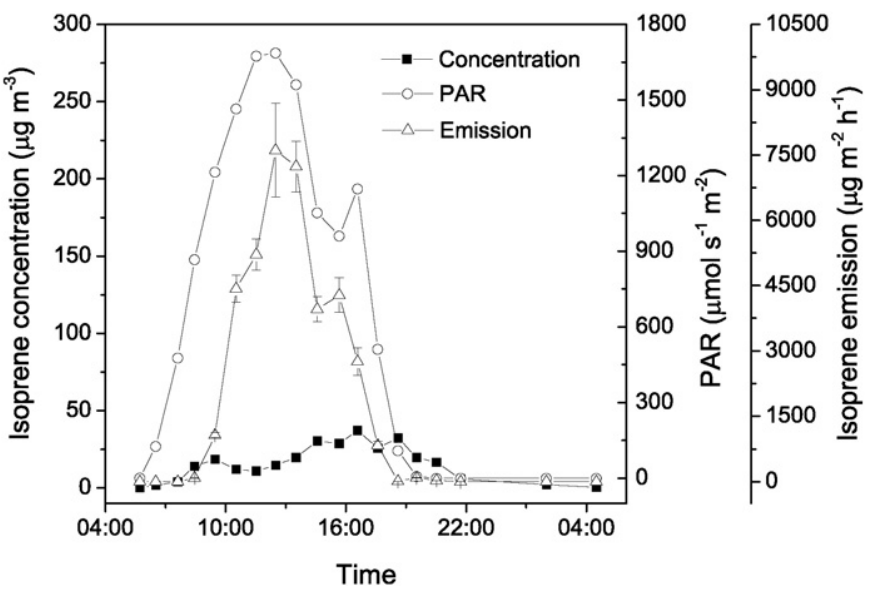

Fig. 4. Diurnal variations in isoprene emission, ambient isoprene concentration and PAR.

\section{Discussions}

\subsection{High ambient monoterpenes concentration in A. frigida-dominated grassland}

As expected, degradation-induced species changes significantly increased ambient BVOCs concentration in the semi-arid grassland. Compared to non-degraded grass areas, concentrations of monoterpenes were about 180 times higher at the sites dominated by subshrub $-A$. frigida, a preponderant species under drought stress and over-grazing in Inner Mongolia. In $A$. frigida- dominated areas with biomass $\geq 1000 \mathrm{~g} \mathrm{~m}^{-2}$, the concentration of monoterpenes ranged from 94.5 to $186.1 \mu \mathrm{g} \mathrm{m}^{-3}$ in hot and sunny days (Temperature $\geq 25^{\circ} \mathrm{C}$ and PAR $\geq 1000 \mu \mathrm{mol} \mathrm{s}^{-1} \mathrm{~m}^{-2}$ ). Such high concentrations were at least an order of magnitude higher than reported maximum values in most other studies in forest ecosystems (Clement et al., 1990; Hakola et al., 2012; Hakola et al., 2003; Harrison et al., 2001; Noe et al., 2012), although the biomass in grassland is much lower than tree biomass in forest. The possible reason for such high concentration is that $A$. frigida contains high amounts of essential oil ( $1.5 \% w / w$ dry basis), in which monoterpenes and oxygenated monoterpenes accounted for 10.4 and 75.6\%, respectively (Lopes-Lutz et al., 2008). Based on the diurnal pattern of monoterpene emission, the emission from $A$. frigida is lightdependent (Fig. 3b), similar to some species such as oak and beech (Dindorf et al., 2006; Staudt and Seufert, 1995) but different from most coniferous trees (Hakola et al., 2000; Juuti et al., 1990; Noe et al., 2012; Tarvainen et al., 2005).Thus, strong sun light $\left(1125 \mu \mathrm{mol} \mathrm{s}{ }^{-1} \mathrm{~m}^{-2}\right.$ in average) during our measurements in the grassland might be another reason for the observed high concentrations. Therefore, the increase of A. frigida resulting from over-grazing and climate change in grassland may raise ambient BVOCs concentration by more than 100 times, and also possibly results in increasingly detected odor if environmental stresses continue to increase (Peñuelas, 2008; Peñuelas and Staudt, 2010). In the grassland ecosystems where NOx levels are relatively low, the high ambient BVOCs concentration may significantly affect the atmospheric chemistry via reacting with the $\mathrm{OH}$ radicals, which will increase the lifetime of $\mathrm{CH}_{4}$, an important greenhouse gas ( $\mathrm{Di}$ Carlo et al., 2004).

\subsection{Grassland might be a potential isoprene source in future}

Isoprene concentrations we observed in Inner Mongolia were similar to reported values ranging from 0.1 to $7.5 \mu \mathrm{g} \mathrm{m}^{-3}$ in boreal forest (Lappalainen et al., 2009; Noe et al., 2012). Based on the regression analysis, sedge was the main contributor, although only small sedge patches existed in our study areas. Bai et al. (2006) also found that isoprene emission from grassland in Inner Mongolia mainly came from sedge 
(Bai et al., 2006). Different from ambient samples collected by canisters, we found much higher isoprene concentration roughly at zero minute in the chamber. This might be caused by high isoprene emission that can increase isoprene concentration from 0 to $100 \mu \mathrm{g} \mathrm{m}^{-3}$ within $20 \mathrm{~s}$ based on the emission rate. Recently, growing evidence showed that isoprene emission from sedge in high-latitude wetlands was unexpectedly high (Ekberg et al., 2009; Faubert et al., 2010; Holst et al., 2010; Patrick et al., 2011; Tiiva et al., 2007a, 2007b) and that nitrogen deposition significantly and quickly increased sedge coverage in grassland (Bassin et al., 2007; Bowman et al., 2008) because sedge grows well in acidic soil. Moreover, our diurnal observation showed that sedge (C. korshinskyi Kom) in semi-arid grassland emitted isoprene at a high rate ( $>9 \mathrm{mg} \mathrm{m}^{-2} \mathrm{~h}^{-1}$ ) compared to boreal wetlands, possibly due to drought and high temperature $\left(>25^{\circ} \mathrm{C}\right)$. This indicates that drought and warming might significantly increase isoprene emission from sedge-dominated, high-latitude meadows in the future. Therefore, grassland may be also a potential isoprene source under climate change.

Supplementary data to this article can be found online at http://dx. doi.org/10.1016/j.scitotenv.2015.10.022.

\section{Acknowledgments}

We thank J. Meng for her help in the field measurement. We also thank K. M. Yang and A. B. Huang in East \& West Analytical Instruments for the technical support in GC analysis. This study was funded by the National Natural Science Foundation of China (20907071/41025012), State Key Laboratory of Organic Geochemistry (OGL-200801) and Youth Innovation Promotion Association of Chinese Academy of Sciences. H. Wang and X. Wang contributed equally to this work.

\section{References}

Bai, J., Baker, B., Liang, B., Greenberg, J., Guenther, A., 2006. Isoprene and monoterpene emissions from an Inner Mongolia grassland. Atmos. Environ. 40, 5753-5758.

Bassin, S., Volk, M., Suter, M., Buchmann, N., Fuhrer, J., 2007. Nitrogen deposition but not ozone affects productivity and community composition of subalpine grassland after 3 yr of treatment. New Phytol. 175, 523-534.

Bowman, W., Cory, C.C., Ĺuboš, H., Juraj, H., Jill, S.B., 2008. Negative impact of nitrogen deposition on soil buffering capacity. Nat. Geosci. 1, 767-770.

Clement, B., Riba, M.L., Leduc, R., Haziza, M., Torres, L., 1990. Concentration of monoterpenes in a maple forest in Quebec. Atmos. Environ. 24, 2513-2516.

Di Carlo, P., Brune, W.H., Martinez, M., Harder, H., Lesher, R., Ren, X.R., et al., 2004. Missing $\mathrm{OH}$ reactivity in a forest: evidence for unknown reactive biogenic VOCs. Science 304, $722-725$.

Dindorf, T., Kuhn, U., Ganzeveld, L, Schebeske, G., Ciccioli, P., Holzke, C, et al, 2006. Significant light and temperature dependent monoterpene emissions from European beech (Fagus sylvatica L.) and their potential impact on the European volatile organic compound budget. J. Geophys. Res. 111. http://dx.doi.org/10.1029/2005JD006751.

Ekberg, A., Arneth, A., Hakola, H., Hayward, S., Holst, T., 2009. Isoprene emission from wetland sedges. Biogeosciences 6, 601-613.

Faubert, P., Tiiva, P., Rinnan, A., Michelsen, A., Holopainen, J., Rinnan, R., 2010. Doubled volatile organic compound emissions from subarctic tundra under simulated climate warming. New Phytol. 187, 199-208.

Frost, C.J., Mescher, M.C., Carlson, J.E., De Moraes, C.M., 2008. Plant defense priming against herbivores: getting ready for a different battle. Plant Physiol. 146, 818-824.

Fuentes, J.D., Hayden, B.P., Garstang, M., Lerdau, M., Fitzjarrald, D., Baldocchi, D.D., et al., 2001. New directions: VOCs and biosphere-atmosphere feedbacks. Atmos. Environ. 35, 189-191.

Guenther, A., Hewitt, C.N., Erickson, D., Fall, R., Geron, C., Graedel, T., et al., 1995. A global model of natural volatile organic compound emissions. J. Geophys. Res. 100, 8873-8892.

Guenther, A., Karl, T., Harley, P., Wiedinmyer, C., Palmer, P.I., Geron, C., 2006. Estimates of global terrestrial isoprene emissions using MEGAN (Model of Emissions of Gases and Aerosols from Nature). Atmos. Chem. Phys. 6, 3181-3210.

Hakola, H., Laurila, T., Rinne, J., Puhto, K., 2000. The ambient concentrations of biogenic hydrocarbons at a northern European, boreal site. Atmos. Environ. 34, 4971-4982.
Hakola, H., Tarvainen, V., Laurila, T., Hiltunen, V., Hellén, H., Keronen, P., 2003. Seasonal variation of VOC concentrations above a boreal coniferous forest. Atmos. Environ. 37, 1623-1634

Hakola, H., Hellén, H., Hemmilä, M., Rinne, J., Kulmala, M., 2012. In situ measurements of volatile organic compounds in a boreal forest. Atmos. Chem. Phys. 12, 11665-11678.

Harrison, D., Hunter, M.C., Lewis, A.C., Seakins, P.W., Bonsang, B., Gros, V., et al., 2001. Ambient isoprene and monoterpene concentrations in a Greek fir (Abies borisii-regis) forest. Reconciliation with emissions measurements and effects on measured $\mathrm{OH}$ concentrations. Atmos. Environ. 35, 4699-4711.

Holst, T., Arneth, A., Hayward, S., Ekberg, A., Mastepanov, M., Jackowicz-Korczynski, M., et al., 2010. BVOC ecosystem flux measurements at a high latitude wetland site. Atmos. Chem. Phys. 10, 1617-1634

Idso, S., 1992. Shrubland expansion in the American Southwest. Clim. Chang. 22, 85-86.

Juuti, S., Arey, J., Atkinson, R., 1990. Monoterpene emission rate measurements from a Monterey pine. J. Geophys. Res. 95, 7515-7519.

Lappalainen, H., Sevanto, S., Bäck, J., Ruuskanen, T., Kolari, P., Taipale, R., et al., 2009. Daytime concentrations of biogenic volatile organic compounds in a boreal forest canopy and their relation to environmental and biological factors. Atmos. Chem. Phys. 9, 5447-5459.

Lerdau, M., 2007. Ecology: a positive feedback with negative consequences. Science 316.

Lerdau, M., Slobodkin, L., 2002. Trace gas emissions and species- dependent ecosystem services. Trends Ecol. Evol. 17, 309-312.

Liu, G., 2003. Analysis on dynamics in grassland of Xilinguole based on technology of remote sensing, geographical information and global position system (Ph.D. thesis) p. 82.

Lopes-Lutz, D., Alviano, D., Alviano, C., Kolodziejczyk, P., 2008. Screening of chemical composition, antimicrobial and antioxidant activities of Artemisia essential oils. Phytochemistry 69, 1732-1738.

Loreto, F., Schnitzler, J.P., 2010. Abiotic stresses and induced BVOCs. Trends Plant Sci. 15, 154-166.

Morgan, J.A., Milchunas, D.G., LeCain, D.R., West, M., Mosier, A.R., 2007. Carbon dioxide enrichment alters plant community structure and accelerates shrub growth in the shortgrass steppe. Proc. Natl. Acad. Sci. U. S. A. 104, 14,724-14,729.

Noe, S.M., Hüve, K., N, Ü., Copolovici, L., 2012. Seasonal variation in vertical volatile compounds air concentrations within a remote hemiboreal mixed forest. Atmos. Chem. Phys. 12, 3909-3926.

Patrick, F., Päivi, T., Tchamga Achille, N., Jarmo, K.H., Toini, H., Riikka, R., 2011. Nonmethane biogenic volatile organic compound emissions from boreal peatland microcosms under warming and water table drawdown. Biogeochemistry 106, 503-516.

Peñuelas, J., 2008. An increasingly scented world. New Phytol. 180, 735-738.

Peñuelas, J., Llusià, J., 2003. BVOCs: plant defense against climate warming? Trends Plant Sci. 8, 105-109.

Peñuelas, J., Staudt, M., 2010. BVOCs and global change. Trends Plant Sci. 15, 133-144.

Shallcross, D.E., Monks, P.S., 2000. New directions: a role for isoprene in biosphere-climate-chemistry feedbacks. Atmos. Environ. 34, 1659-1660.

Staudt, M., Seufert, G., 1995. Light-dependent emission of monoterpenes by holm oak (Quercus ilex L.). Naturwissenschaften 82, 89-92.

Tarvainen, V., Hakola, H., Hellén, H., Bäck, J., Hari, P., Kulmala, M., 2005. Temperature and light dependence of the VOC emissions of Scots pine. Atmos. Chem. Phys. 5, 989-998.

Tiiva, P., Rinnan, R., Faubert, P., Räsänen, J., Holopainen, T., Kyrö, E., et al., 2007a. Isoprene emission from a subarctic peatland under enhanced UV-B radiation. New Phytol. 176, 346-355.

Tiiva, P., Rinnan, R., Holopainen, T., Mörsky, S.K., Holopainen, J.K., 2007b. Isoprene emissions from boreal peatland microcosms; effects of elevated ozone concentration in an open field experiment. Atmos. Environ. 41, 3819-3828.

Valolahti, H., Kivimäenpää, M., Faubert, P., Michelsen, A., Rinnan, R., 2015. Climate change-induced vegetation change as a driver of increased subarctic biogenic volatile organic compound emissions. Glob. Chang. Biol. http://dx.doi.org/10.1111/gcb.12953.

Wang, X., Wu, T., 2008. Release of isoprene and monoterpenes during the aerobic decomposition of orange wastes from laboratory incubation experiments. Environ. Sci. Technol 42, 3265-3270.

Wang, H., Xia, J., Mu, Y., Nie, L., Han, X., Wan, S., 2012. BVOCs emission in a semi-arid grassland under climate warming and nitrogen deposition. Atmos. Chem. Phys. 12, 3809-3819.

Werger, M.J., van Staalduinen, M.A., 2012. Eurasian Steppes. Ecological Problems and Livelihoods in a Changing World 6. Springer Science \& Business Media.

Yi, Z., Wang, X., Sheng, G., Zhang, D., Zhou, G., Fu, J., 2007. Soil uptake of carbonyl sulfide in subtropical forests with different successional stages in south China. J. Geophys. Res. 112. http://dx.doi.org/10.1029/2006JD008048.

Zhang, Y., Wang, X., Barletta, B., Simpson, I.J., Blake, D.R., Fu, X., et al., 2013. Source attributions of hazardous aromatic hydrocarbons in urban, suburban and rural areas in the Pearl River Delta (PRD) region. J. Hazard. Mater. 250, 403-411. 